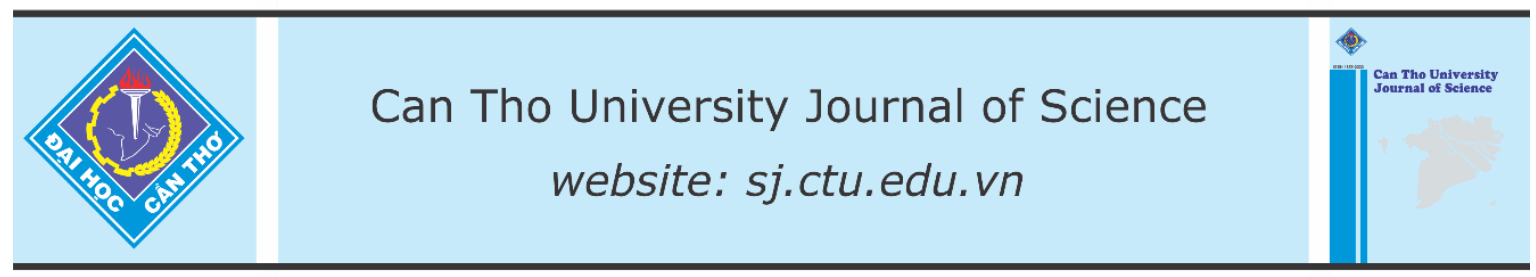

DOI: 10.22144/ctu.jen.2020.019

\title{
EFL lecturers' needs for professional development: A case study of an institution in the Mekong Delta
}

\author{
Le Xuan Mai*
}

School of Foreign Languages, Can Tho University, Vietnam

*Correspondance: Le Xuan Mai (email: lxmai@ctu.edu.vn)

\section{Article info.}

Received 25 Apr 2020

Revised 15 Jun 2020

Accepted 30 Nov 2020

\section{Keywords}

English Teacher Competency

Framework, EFL lecturers, needs, professional development, self-evaluation

\begin{abstract}
Professional development is considered as an essential element in improving teachers' competencies which, in turn, enhance students' learning outcomes. In order to provide useful input for the design of more effective and productive professional training programs, this small-scale study was conducted to investigate EFL lecturers' strengths and weaknesses, and their needs for professional development. Seventeen lecturers were recruited for this descriptive study; they provided information via questionnaire and four of them participated in semi-structured interviews. The English Teacher Competency Framework was mainly used to explore the lecturers' strengths and weaknesses on five domains, namely knowledge of subject, knowledge of teaching, knowledge of learners, professional attitudes and values, and practice and context of language teaching. The semi-structured interview was employed to get more information about their needs for professional development. Almost all EFL lecturer participants in this study reported a high level of confidence on all domains. The common professional development activities that the lecturers need more training or sharing refer to their teaching (e.g. teaching language skills, techniques for classroom management and groupwork management, designing lesson plans for mixed ability class) and their own learning (e.g. reading professional materials and resources, participating activities related to professional community, observing colleagues' teaching, and attending seminars, workshops or conferences). The findings from this study raise the lecturers' awareness of their own strengths, weaknesses and needs as well as inform training program developers and administrators in designing appropriate professional training programs and suggest related research areas in the future.
\end{abstract}

Cited as: Mai, L.T., 2020. EFL lecturers' needs for professional development: A case study of an institution in the Mekong Delta. Can Tho University Journal of Science. 12(3): 7-16. 


\section{INTRODUCTION}

Professional development (PD) plays an important role for in-service teachers' career path (Shawer, 2010; Richards \& Ferrell, 2011). The teachers need to have opportunities for PD because they have to keep their knowledge and skills updated (Richards $\&$ Farrell, 2005). The language teachers also follow this rule without exception. It is obvious that language teaching profession encounters challenges of continuous changes or reforms in terms of educational paradigms, curriculum trends, national tests, assessment, student needs or technology. Moreover, teachers' knowledge about language teaching and learning is provided at pre-service training, but this kind of knowledge is not always sufficient, so teachers need to update current knowledge, approaches and other developments in the field. As a result, PD is a good way to bridge the gap between what the teachers have already possessed and what they need to update and improve.

Vietnam has been a member of different international organizations such as Association of Southeast Asian Nations (ASEAN), Asia Pacific Economic Cooperation (APEC), and the World Trade Organization (WTO). In order to better prepare Vietnamese citizens for the globalization and internationalization, the Government has issued policies and plans to promote foreign language teaching and learning in Vietnam, especially English (Prime Minister, 2008).

In response to the demand of the world and $\mathrm{Vi}-$ etnam, Can Tho University has issued a decision on promoting teaching and learning foreign languages. However, in reality, despite the policies and action plans on promoting foreign language teaching and learning, particularly English, nationally, locally and institutionally, students' English proficiency is generally low, especially the students in the Mekong Delta. The results from the annual placement tests for freshmen at Can Tho University showed that more than $80 \%$ of the freshmen need to take basic English courses since 2015. Therefore, improving the quality of English language teaching should be emphasized with the attention of providing a wide range of opportunities for in-service teachers to participate in PD activities. The implementation of PD is likely to be a beneficial way for teachers to maintain high quality of teaching (Mahmoudi \& Özkan, 2015).

With relation to government policies of educational reform, PD programs are given a great emphasis to maintain a high standard of teaching and to retain a high-quality teacher staff (Prime Minister, 2008). Therefore, a number of PD programs for EFL teachers at K12 including short courses, seminars, workshops, and certificate programs have been developed. However, these PD programs have not been applied for EFL lecturers at tertiary education. Therefore, it is essential to consider PD programs for EFL lecturers. In order to organize effective PD programs and activities, it is necessary to explore the EFL lecturers' self-evaluation of their strengths or weaknesses, and their needs for professional development training. Consequently, this study was conducted to meet these aims.

\section{LITERATURE REVIEW}

\subsection{Definition of terms}

In this section, the definitions of professional development, self-evaluation and needs are provided. Professional development (PD) is defined by different authors (Birman et al., 2000; Richards \& Ferrell, 2005; Shawer, 2010; Johnson \& Golombek, 2011; Richards \& Ferrell, 2011). In general, PD is understood as a life-long learning process including activities through which in-service teachers can improve professional skills and knowledge during their career to raise the quality of students' learning. Selfevaluation is defined as "a judgment made by an employee about their own work, abilities, etc., or the process of doing this" by Cambridge dictionary online (https://dictionary.cambridge.org). Finally, needs refers to "the things you must have for a satisfactory life"; in other words, needs in this study refers to the expectations or what the lecturers want to have for their professional development.

\subsection{Vietnam's English Teacher Competency Framework}

Vietnam's English Teacher Competency Framework (ETCF), approved in December 2012 by the Ministry of Education and Training, is a standardized tool for teacher development which helps to raise the quality of English teaching and learning in Vietnam. The ETCF provides a detail of the competencies, knowledge, skills, values and processes to make well-equipped teachers for English teaching in Vietnam in the early 21 st century. It is not only a guide for teachers to self-study for continuous PD during their career, but also a tool for teacher trainers to evaluate teachers' needs and identify specific areas for the content of training programs and teacher development (Ministry of Education and Training, 2013). 
ETCF is based on five domains including knowledge of subject, knowledge of teaching, knowledge of learners, professional attitudes and values, and practice and context of language teaching. In each domain, there are different competencies. There is a questionnaire designed based on the ETCF for teachers to self-evaluate the teachers' strengths and weaknesses or needs (for details, see Section 4). This questionnaire was employed in this study as a tool to explore the EFL lecturers' strengths and weaknesses.

\subsection{Related studies}

A number of previous studies the teachers' need for PD training. In some studies, the teachers need to improve both English language proficiency and teaching methodology. For example, in a study by Igawa (2008) studying 44 secondary EFL teachers in Japan and Korea, the results indicate that teachers need to improve teaching skills and methods, and language proficiency. Similarly, in Noom-Ura's (2013) study, 34 secondary EFL teachers in Thailand expected to strengthen teaching strategies, and attend training courses on English proficiency development. Another study done by Zein (2016) investigated $20 \mathrm{EFL}$ primary teachers' needs. The results showed that the teachers needed improvement of language proficiency and pedagogical skills which was in line with the findings of the study by Le and Nguyen (2019). Regarding pedagogical skills, the teachers needed to develop skills on classroom management, language skill integration, lesson planning, and material selection and adaptation.

In other studies, the teachers' needs refer to more training about teaching methodology. For example, in the English teaching context of Turkey, Özdemir (2013) investigated 507 elementary and secondary teachers. The teachers needed to be trained in new instructional approaches, methods and techniques. In addition, Roux and Valladares (2014) conducted a study with 297 secondary EFL teachers in Mexico. These Mexican teachers wanted to learn more about lesson planning, then learn more about technologies to strengthen their teaching. Finally, in the context of Iran, Alibakhshi and Dehvari (2015) interviewed 20 EFL high school teachers. These teachers' needs include teaching methodology, test preparation, material adaptation, and the use of technology.

Most previous studies focused on exploring teachers' expectations or needs for PD training, but not many studies explore the teachers' strengths and weaknesses and identify whether their expectations and weaknesses are aligned or not. This study aimed to fill the gap.

\section{THE STUDY}

This study was guided by two research questions:

1.What are EFL lecturers' self-evaluation of their strengths and weaknesses?

2.What are EFL lecturers' needs for professional development training?

To identify the EFL lecturers' self-evaluation of their strengths and weaknesses and their needs for PD training, a descriptive case study was employed. The main methods for data collection were questionnaire and semi-structured interviews. The questionnaire is based on the survey on ETCF teacher strengths and needs assessment. The semi-structured interview was used to explore more in-depth information on the $2^{\text {nd }}$ research question on the lecturers' needs. The interviewing plays an important role in the data collection process. It not only serves as a triangulation method but also a method to explore details and more insights into the issue because the participants do not always have opportunities to provide details when completing questionnaire.

Table 1: Participants' Information ( $N=17)$

\begin{tabular}{|c|c|c|c|}
\hline \multicolumn{2}{|c|}{ Information } & \multicolumn{2}{|c|}{ Number Percentage } \\
\hline \multirow{2}{*}{ Gender } & Female & 15 & 88.2 \\
\hline & Male & 02 & 11.8 \\
\hline \multirow{3}{*}{$\begin{array}{l}\text { Teaching } \\
\text { experiences }\end{array}$} & Below & 02 & 11.8 \\
\hline & $6 \mathrm{tc}$ & 11 & 64.7 \\
\hline & years & 04 & 23.5 \\
\hline \multirow{3}{*}{\multicolumn{2}{|c|}{$\begin{array}{c}\text { Workplaces School of For- } \\
\text { eign Languages } \\
\text { Inviting lecturers }\end{array}$}} & 06 & 35 \\
\hline & & 04 & 23.5 \\
\hline & & 07 & 41.2 \\
\hline
\end{tabular}

The results of this study are presented in the next section.

The participants in this study were the EFL lecturers who teach general English for the institution. There were 17 lecturers who agreed to participate in the survey. Table 1 provides the summary of participants' information, including gender, teaching experiences and workplaces. Among them, four female lecturers agreed to attend the semi-structured interviews. These lecturers were recruited based on their willingness to participate in the study and their teaching experience: one lecturer with 4 years of teaching experience (classified as early career), two lecturers with 9 and 13 years of teaching experience 
(mid-career), and one lecturer with 20 years of teaching experience (late career). The research wanted to explore if the lecturers' needs for PD activities with various teaching experience are similar or not.

\section{RESULTS}

\subsection{The EFL lecturers' self-evaluation of their strengths and weaknesses}

The results from the questionnaire about the lecturers' self-evaluation of their confident level (their strengths) in five domains are presented in Table 2 to Table 6 accordingly. Table 2 summarizes the results in Domain 1 including 17 items, which refers to knowledge of language, language learning and language content and curriculum.

In general, the lecturers reported that they are confident or very confident about their knowledge of language, language learning and language content and curriculum. In particular, most lecturers (over 70\%) felt very confident in understanding the English curriculum they are required to use (Item 16) and using textbooks and required curriculum objectives when planning lessons (Item 17). Many lecturers (64.7\%) were also very confident on the following aspects: understand English sounds, word parts, word meanings, and word order (Item 5), know how languages are learned (Item 7), and apply this knowledge to my own language learning (Item 8). On the contrary, only one aspect was reported as not very confident by some lecturers (29.4\%); that is using English literature to teach language and content (Item 13). For the other aspects in this domain, none or few of the lecturers $(5.9 \%-11.8 \%)$ reported as not very confident. Therefore, it seems that the lecturers have strengths in this domain.

Next, Table 3 summarizes the results in Domain 2 including 15 items, which refers to knowledge of language teaching.

Table 2: Domain 1 (Knowledge of language, language learning \& language content and curriculum)

\begin{tabular}{lrrr}
\hline Items & $\begin{array}{r}\text { Not very } \\
\text { confident } \\
(\mathbf{\%})\end{array}$ & $\begin{array}{r}\text { Somewhat } \\
\text { confident } \\
(\%)\end{array}$ & $\begin{array}{r}\text { Very confi- } \\
\text { dent } \\
(\%)\end{array}$ \\
\hline 1. I can use English at the level required for my teaching (C1). & 0 & 58.8 & 41.2 \\
2. I can find opportunities to strengthen my English proficiency. & 11.8 & 41.2 & 47.1 \\
3. I understand the CEF / KNLNN proficiency descriptors at the & 5.9 & 47.1 & 47.1 \\
levels that apply to my students. & 5.9 & 52.9 & 41.2 \\
4. I can apply that understanding to my teaching practice. & 5.9 & 29.4 & $\mathbf{6 4 . 7}$ \\
5. I understand English sounds, word parts, word meanings, and & 0 & 52.9 & 47.1 \\
word order. & 0 & 35.3 & $\mathbf{6 4 . 7}$ \\
6. I can teach these things in my classes. & 5.9 & 29.4 & $\mathbf{6 4 . 7}$ \\
7. I know how languages are learned. & 0 & 76.5 & 23.5 \\
8. I can apply this knowledge to my own LANGUAGE LEARN- & 5.9 & 70.6 & 23.5 \\
ING. & 11.8 & 64.7 & 23.5 \\
9. I can apply this knowledge to my TEACHING. & 11.8 & 70.6 & 17.6 \\
10. I know about English-speaking cultures. & $\mathbf{2 9 . 4}$ & 64.7 & 5.9 \\
11. I can include this cultural knowledge in my teaching. & 0 & 52.9 & 47.1 \\
12. I can use this cultural knowledge to build understanding and em- \\
pathy.
\end{tabular}


Table 3: Domain 2 (Knowledge of language teaching)

\begin{tabular}{|c|c|c|c|}
\hline Items & 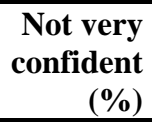 & $\begin{array}{r}\text { Somewhat } \\
\text { confident } \\
(\%) \\
\end{array}$ & $\begin{array}{r}\text { Very } \\
\text { confident } \\
(\%) \\
\end{array}$ \\
\hline 1. I KNOW many strategies and techniques to integrate the 4 skills. & 5.9 & 70.6 & $\overline{23.5}$ \\
\hline 2. I can USE many strategies and techniques to integrate 4 skills. & 5.9 & 70.6 & 23.5 \\
\hline $\begin{array}{l}\text { 3. I can use language teaching methodology to integrate the } 4 \text { skills for au- } \\
\text { thentic communication. }\end{array}$ & 5.9 & 70.6 & 23.5 \\
\hline $\begin{array}{l}\text { 4. I can use language teaching methodology to integrate } 4 \text { skills to teach dif- } \\
\text { ferent kinds of learners. }\end{array}$ & 11.8 & 58.8 & 29.4 \\
\hline $\begin{array}{l}\text { 5. I understand what kinds of lessons, assignments and activities teach con- } \\
\text { tent, integrate skills, and help students learn English. }\end{array}$ & 5.9 & 41.2 & 52.9 \\
\hline $\begin{array}{l}\text { 6. I can plan effective lessons and design assignments and activities to teach } \\
\text { content, integrate skills and help students learn English. }\end{array}$ & 11.8 & 70.6 & 17.6 \\
\hline 7. I know how to create a supportive, meaningful learning environment. & 5.9 & 52.9 & 41.2 \\
\hline $\begin{array}{l}\text { 8. I can USE THE LESSON PLAN to teach students, and give them mean- } \\
\text { ingful opportunities to communicate. }\end{array}$ & 5.9 & 47.1 & 47.1 \\
\hline $\begin{array}{l}\text { 9. I can MANAGE CLASSROOM ACTIVITIES to teach students, and give } \\
\text { them meaningful opportunities to communicate. }\end{array}$ & 5.9 & 52.9 & 41.2 \\
\hline $\begin{array}{l}\text { 10. I know about formative (ongoing) and summative (progress) assessment } \\
\text { tools and techniques. }\end{array}$ & 11.8 & 52.9 & 35.3 \\
\hline $\begin{array}{l}\text { 11. I can design and use age-appropriate assessment tools to guide my teach- } \\
\text { ing and measure student progress. }\end{array}$ & 17.6 & 52.9 & 29.4 \\
\hline 12. I can use and adapt textbooks effectively for my teaching. & 0 & 41.2 & 58.8 \\
\hline $\begin{array}{l}\text { 13. I can find and adapt materials and resources that are suitable for students' } \\
\text { age and English level. }\end{array}$ & 0 & 47.1 & 52.9 \\
\hline 14. I have basic computer skills and can use basic computer programs. & 0 & 29.4 & 70.6 \\
\hline 15. I can use technology for language teaching and learning. & 0 & 52.9 & 47.1 \\
\hline
\end{tabular}

Similar to Domain 1, almost all lecturers reported that they are mostly confident and even very confident on their knowledge of language teaching. According to the results, most lecturers (over 70\%) felt very confident with their basic computer skills and they could use basic computer programs (Item 14). Many of them were also very confident that they can use and adapt textbooks as well as find and adapt

materials plus resources for their teaching (Items $12 \& 13$ ) and they understand what kinds of lessons, assignments and activities teach content, integrate skills, and help students learn English (Item 5). In this Domain, none or few lecturers reported as not very confident. Therefore, similar to Domain 1 , it seems that the lecturers also have strengths in Domain 2 .

Table 4: Domain 3 (Knowledge of language learners)

\begin{tabular}{|c|c|c|c|}
\hline Items & $\begin{array}{r}\text { Not very } \\
\text { confident } \\
(\%) \\
\end{array}$ & $\begin{array}{r}\text { Somewhat } \\
\text { confident } \\
(\%) \\
\end{array}$ & $\begin{array}{r}r y \text { con- } \\
\text { fident } \\
(\%) \\
\end{array}$ \\
\hline 1. I understand learners' intellectual and emotional development. & 11.8 & 64.7 & 23.5 \\
\hline 2. I know about different learning styles. & 11.8 & 41.2 & 47.1 \\
\hline 3. I can develop lessons that motivate different kinds of learners. & 23.5 & 52.9 & 23.5 \\
\hline 4. I know about different stages of language development. & 17.6 & 52.9 & 29.4 \\
\hline $\begin{array}{l}\text { 5. I can adapt my teaching and give feedback on students' errors in ways that } \\
\text { are suitable to their language level. }\end{array}$ & 5.9 & 47.1 & 47.1 \\
\hline $\begin{array}{l}\text { 6. I can reflect on MY cultural values and learning experiences and how } \\
\text { these affect my learning and teaching. }\end{array}$ & 35.3 & 23.5 & 41.2 \\
\hline $\begin{array}{l}\text { 7. I can reflect on my STUDENTS' cultural values and prior learning experi- } \\
\text { ences and how they affect students' learning and behavior. }\end{array}$ & 35.3 & 35.3 & 29.4 \\
\hline $\begin{array}{l}\text { 8. I can practice creativity and critical thinking in their my learning and } \\
\text { teaching }\end{array}$ & 17.6 & 52.9 & 29.4 \\
\hline $\begin{array}{l}\text { 9. I can help my students develop creativity and critical thinking appropriate } \\
\text { for their age. }\end{array}$ & 17.6 & 64.7 & 17.6 \\
\hline
\end{tabular}


Next, Table 4 summarizes the results in Domain 3 including 09 items, which refers to knowledge of language learners.

Unlike the results of Domain 1 and Domain 2, the lecturers did not report their very high confident level in this Domain about knowledge of language learners although the overall percentages are not low. In this Domain, a number of lecturers (35.3\%) even felt less confident on the following aspects: reflecting on their cultural values and learning experi- ences and how these affect their learning and teaching (Item 6), reflecting on their students' cultural values and prior learning experiences and how they affect students' learning and behavior (Item 7). A few lecturers (23.5\%) did not feel very confident in developing lessons that motivate different kinds of learners (Item 3).

Next, Table 5 summarizes the results in Domain 4 including 08 items, which refers to professional attitudes and values in language teaching.

Table 5: Domain 4 (Professional attitudes \& values in language teaching)

\begin{tabular}{lrrr}
\hline Items & $\begin{array}{r}\text { Not very } \\
\text { confident } \\
(\mathbf{\%})\end{array}$ & $\begin{array}{r}\text { Somewhat } \\
\text { confident } \\
(\mathbf{\%})\end{array}$ & $\begin{array}{r}\text { Very } \\
\text { confident } \\
(\mathbf{\%})\end{array}$ \\
\hline 1. I value and can promote the importance of learning English. & 0 & 52.9 & 47.1 \\
2. I can teach and behave professionally. & 0 & 35.3 & $\mathbf{6 4 . 7}$ \\
3. I can collaborate with others in teams to accomplish tasks. & 5.9 & 29.4 & $\mathbf{6 4 . 7}$ \\
4. I can teach STUDENTS cooperation and collaboration skills. & 5.9 & 47.1 & 47.1 \\
5. I can learn new information about language teaching and re- & 11.8 & 35.3 & $\mathbf{5 2 . 9}$ \\
search on my own. & 5.9 & 41.2 & $\mathbf{5 2 . 9}$ \\
6. I can develop teaching skills on my own. & $\mathbf{2 3 . 5}$ & 41.2 & 35.3 \\
7. I can find ongoing professional development opportunities. & 5.9 & 47.1 & 47.1 \\
8. I can contribute to the exchange of ideas in my teaching commu- & & \\
nity to benefit other teachers. & &
\end{tabular}

The results show the positive self-evaluation by the lecturers about their professional attitudes and values in teaching. Particularly, two items (Items 5 and 6) receive the highest percentages at the level of very confident (64.7\%); these items refer to learning new information about language teaching and research by themselves and developing teaching skills by themselves, respectively. The next high level of very confident $(52.9 \%)$ refers to teaching and behaving professionally (Item 2), collaborating with others in teams to accomplish tasks (Item 3). On the contrary, some lecturers $(23.5 \%)$ did not feel confident on the issue of ongoing professional development opportunities (Item 7).

Finally, Table 6 summarizes the results in Domain 5 including 05 items, which refers to practice and context of language teaching.

Table 6: Domain 5 (Practice \& context of language teaching)

\begin{tabular}{lccc}
\hline Items & $\begin{array}{r}\text { Not very } \\
\text { confident } \\
(\mathbf{\%})\end{array}$ & $\begin{array}{r}\text { Somewhat Very confi- } \\
\text { confident } \\
(\mathbf{\%})\end{array}$ & $\begin{array}{r}\text { dent } \\
\mathbf{( \% )}\end{array}$ \\
\hline $\begin{array}{l}\text { 1. I can continue to learn about current topics that are important } \\
\text { for English teaching. }\end{array}$ & 11.8 & 35.3 & $\mathbf{5 2 . 9}$ \\
\hline $\begin{array}{l}\text { 2. I can connect my students' English learning to other students, } \\
\text { classes, school, and topics. }\end{array}$ & 11.8 & 52.9 & 35.3 \\
\hline $\begin{array}{l}\text { 3. I can practice ongoing reflection to THINK ABOUT MY } \\
\text { OWN LANGUAGE LEARNING. }\end{array}$ & 17.6 & 41.2 & 41.2 \\
\hline $\begin{array}{l}\text { 4. I can practice ongoing reflection to FIND ANSWERS TO MY } \\
\text { TEACHING QUESTIONS. }\end{array}$ & 17.6 & 41.2 & 41.2 \\
\hline 5. I can use my reflections to guide my learning and teaching. & 11.8 & 41.2 & 47.1 \\
\hline
\end{tabular}

It can be seen that most lecturers reported that they rated a high level of confidence for all items in this domain. Particularly, more than half of the lecturers reported that they are very confident in learning about current topics that are important for English teaching (Item 1). However, a few of them (from $11.8 \%$ to $17.6 \%$ ) still felt not very confident for all items. 
In conclusion, the EFL lecturers reported a pretty high level of confidence in all five domains. Most of them felt very confident in Domain 1 (Knowledge of language, language learning and language content and curriculum), and Domain 2 (Knowledge of language teaching), but no lecturers self-evaluated that they felt very confident in Domain 3 (Knowledge of language learners) and Domain 5 (Practice and context of language teaching). However, when the EFL lecturers mentioned the domain they need further support, Domain 1 was proposed the most although the percentage is not high $(35.3 \%)$. While the lecturers did not feel very confident in Domains 3 and 5, they did not propose the needs for more support in these domains; only $5.9 \%$ lecturers mentioned they need support in Domains 3 and 5. Further information about the lecturers' need for PD training is presented in the next section.

\subsection{The EFL lecturers' needs for professional development training}

According the data obtained from the questionnaire, the EFL lecturers provided their response in PD activities that they prefer to take. Table 7 provides the summary. As can be seen in Table 7, a number of lecturers (88.2\%) want to read books, journals or access web resources related to their profession (Item 1). Nearly half of the lecturers $(47.1 \%)$ would like to participate in online discussions, blogs, wiki, twitter, and facebook (Item 2). Book clubs, professional learning community, study circles (Item 3), observing other teachers' teaching (Item 5), and joining workshops, podcasts, webinars, and conferences (Item 14) are also the lecturers' needs although these activities are not priorities for many lecturers, only $35.5 \%$. None of the lecturers want to attend summer graduate courses (Item 12), and few of them $(5.9 \%)$ like the following activities: joining mentoring and coaching (Item 6), team teaching/ peer teaching (Item 7), or grant and award application (Item 11). No lecturers mention other PD activities in addition to those in the questionnaire. However, in the interview, they propose more. That is one of the reasons why the interview is important in the data collection process.

Table 7: PD activities preferred by the lecturers

\begin{tabular}{lr}
\hline Items & Percentage (\%) \\
\hline 1. Reading books, journals, \& web resources & $\mathbf{8 8 . 2}$ \\
2. Online discussions, blogs, wiki, twitter, \& facebook & $\mathbf{4 7 . 1}$ \\
3. Book clubs, professional learning community, study circles & $\mathbf{3 5 . 5}$ \\
4. Joining professional organization & 29.4 \\
5. Observing other teachers' teaching & $\mathbf{3 5 . 5}$ \\
6. Joining mentoring and coaching & 5.9 \\
7. Team teaching/ peer teaching & 5.9 \\
8. Publishing reviews, articles \& textbooks & 11.8 \\
9. Joining resource centers & 23.5 \\
10. Joining textbook selection and curriculum development & 17.6 \\
11. Grant and award application & 5.9 \\
12. Attending summer graduate courses & 0 \\
13. Organizing teaching journal, narrative \& e-portfolio & 17.6 \\
14. Joining workshops, podcasts, webinars, and conferences & $\mathbf{3 5 . 5}$ \\
15. Undertaking teacher inquiry/ action research & 11.8 \\
16. Other & 0 \\
\hline
\end{tabular}

Through the semi-structured interviews, the EFL lecturers provide more explanations on their needs for PD training programs and/ or activities. First of all, the PD activity that all interviewed lecturers expect is how to teach language skills. This is not mentioned in the questionnaire, but in the interview all the lecturers agreed that they need more training on this issue although they have been learned and trained so far, but they still want to update on the latest trend in teaching. The second rank in the need list refers to observing other teachers' teaching (Item 5). Teacher 1 (early career) and Teacher 2 (mid-career) shared similar needs. They "would like to have an opportunity to observe other colleagues' teaching, especially a model teaching period". They believe that this activity is useful and authentic because they can share ideas on effective teaching methodology and teaching techniques as well as learn good teaching examples from their colleagues. However, other colleagues who are more experienced in teaching do not need this activity. The third issue that half of the interviewed lecturers (Teacher 2 and Teacher 3, mid-career) would like to attend 
PD session on how to manage the classroom and activities like group work effectively. These lecturers shared similar ideas that they "want to listen to sharing from trainers or colleagues" because they "can learn useful things and effective techniques to help the teaching and learning become more efficient". These lecturers also mention that the "PD activities do not always have to be organized in formal settings, but they can be in informal settings where the lecturers can meet and chat about their accomplishments and failures in class". Finally, only one latecareer lecturer who is also an inviting lecturer want to learn more about designing lesson plans for a mix-proficiency level class. She shares that she feels "worried when teaching a class with different proficiency levels"; she wants to be sure that her "lessons will meet all the students' needs and the lessons attract all students' attention".

In summary, the PD activities that the lecturers need more training or sharing refer to their teaching (e.g. teaching language skills, techniques for classroom management and groupwork management, designing lesson plans for mixed ability class) and their own learning (e.g. reading professional materials and resources, participating activities related to professional community, observing colleagues' teaching, and attending seminars, workshops or conferences). The results of this study are both similar and different from those of previous studies. The next section will provide more information about these.

\section{DISCUSSION}

The results of this study are similar with those found by previous researchers. The lecturers in this study shared similar needs or expectations for PD training as the teachers in studies done by Igawa (2008), Noom-Ura (2013), Özdemir (2013), Roux and Valladares (2014), Alibakhshi and Dehvari (2015), Zein (2016), and Le and Nguyen (2019). These needs or expectations for $\mathrm{PD}$ include teaching language skills, or teaching methods and approaches or techniques, and some specific techniques as classroom management and lesson planning. Although the teaching contexts and levels are different, almost all teachers wanted to update and improve their teaching methodology and pedagogical skills so that they could do their work better and improve the quality of teaching and learning.

On the other hand, some results are different from those of previous studies. First, it is about the need for language improvement. Previous studies showed that the teachers needed to attend PD in order to improve their language proficiency (Igawa, 2008;
Noom-Ura, 2013; Zein, 2016). However, in this study the EFL lecturers did not need that type of training. The reason is that the institution has a policy on the lecturers' language proficiency; the lecturers must obtain $\mathrm{C} 1$ or equivalent English proficiency level in order to teach English at the institution.

Another difference refers to specific areas of PD. For example, the teachers in previous studies (Roux \& Valladares, 2014; Alibakhshi \& Dehvari, 2015; Zein, 2016) expected to have more PD training on teaching with technologies, material selection and adaptations, and test preparation. On the contrary, almost no lecturers in this study proposed these needs. Possible explanations may refer to the teaching context and curriculum. While the K12 teachers need to work at lower level with strict guidelines on what to teach, how to teach and how to administer tests, the lecturers have more freedom in their classes and they have support in test administration from the institution. In addition, many lecturers completed their postgraduate studies in English speaking countries, and the lecturers had more opportunities to attend and present at conferences on English language teaching. As a result, they have more experience and expertise in using technologies, selecting and adapting additional teaching materials. This leads to the fact that their needs for PD are not the same as their colleagues at K12 level.

The final difference refers to observing other teachers' classrooms. For K12 teachers in previous studies, no one indicated this need. Perhaps, this activity is familiar and considered as a routine at their schools. However, at tertiary level, it is not required to attend others' classes. Therefore, the lecturers, especially those who were in early career or inexperienced, could not learn from good practices done by their colleagues, and they expected to have this activity as a part of their PD.

There are some points to note. First, the self-evaluation of lecturers' own strengths and weakness is aligned with their proposed needs to some extent. When they possess strengths on certain aspects, they do not need further PD for these aspects. For example, in Domain 1, the lecturers felt confident and very confident on their English proficiency, so they did not need to attend English proficiency training courses. In Domain 2, the lecturers reported a high level of confidence in selecting and adapting materials and resources, and using technologies in teaching. Therefore, they did not propose their needs in 
these areas, which is different from findings from previous studies on K12 teachers.

On the contrary, the needs and the strengths reported by the lecturers are not always the same. For instance, in Domain 2, the lecturers reported a high level of confidence in integrating four skills in teaching, but in the interviews, the lecturers still proposed the need to attend pedagogical training on teaching four skills. The reasons can be explained as in Section 5.1. In Domain 3, although most lecturers self-evaluated that they can develop lessons that motivate different kinds of learners, they still need further support on designing lesson plans for mixed ability classes. On the other hand, in Domain 5, the lecturers did not report a high level of strengths, but in the needs section, they did not propose any needs to improve their weaknesses.

\section{CONCLUSIONS}

This study has some major findings. First, the EFL lecturers indicate an overall high level of confidence in all domains of competencies required for an EFL teacher. However, the administrators should pay attention to Domains 3 and 5 because the lecturers may need further support. Second, the lecturers still need more PD activities on the following aspects: accessing professional materials/ resources, participating in professional community of practice (faceto-face or via social networks), observing other colleagues' teaching, attending seminars, workshops, conferences, and training on particular pedagogical issues such as teaching languages skills, and designing lesson plans for mixed ability classes.

The results from this study can benefit the lecturers themselves and a number of stakeholders. The lecturers are aware of their strengths, weaknesses and needs or expectations, so they can proactively design and implement their own PD action plan. They now teach at tertiary level, and they have to be independent and autonomous learners rather than passively wait for the PD training organized by the institution. For other stakeholders, such as administrators or PD trainers, they know the lecturers' weaknesses and needs or expectations so that they can design a more appropriate program and activities to meet and trainees' demands. As a result, the outcome of the PD training will be maximized. About the format of the PD activities, it can be either formal like training, workshops and seminars, or merely informal like group discussions face-to-face and via social networks. In addition to PD training, the professional community is very important. It helps the lecturers share experiences and learn useful techniques from their colleagues. Therefore, this practice should be established, implemented and/ or developed. Finally, in order to explore more insights about people's views or perceptions and have accurate understanding about a certain issue, interviewing or talking to people seems to be more effective rather than doing survey.

This study cannot avoid limitations. First of all, the study only focuses on one case, and the number of participants is small, so the results cannot be generalized. Second, within the scope of this study, it did not focus on exploring the challenges or difficulties that the lecturers have encountered to improve their profession. The final limitation is on the use of data collection methods; observation was not employed, but the study used instruments which collects data from self-reported ideas. Consequently, further studies can recruit more participants, and at different levels such as lecturers, administrators and trainers for investigation in order to obtain a more complete view on PD training. The researchers can conduct comparative studies to research about the PD needs of EFL K12 teachers and EFL lecturers. Finally, future studies can explore more issues on PD for lecturers such as beliefs about PD, experiences of PD, satisfaction on $\mathrm{PD}$, challenges for $\mathrm{PD}$, and practices or changes after PD training.

\section{ACKNOWLEDGMENTS}

The researcher would like to express her sincere gratitude to Can Tho University. This study was conducted thanks to the financial support from the University Research Funding. It is hoped that the findings of this study will contribute to facilitating the teaching and learning of English at the university.

\section{REFERENCES}

Alibakhshi, G., \& Dehvari, N., 2015. EFL teachers' perceptions of continuing professional sevelopment: A case of Iranian high school teachers. Profile Issues in Teachers Professional Development, 17(2): 29-42.

Birman, B. F., Desimone, L., Porter, A. C., \& Garet, M. S., 2000. Designing professional development that works. Educational Leadership, 57(8): 28-33.

Prime Minister, 2008. Decision No. 1400/QĐ-TTg, dated 30 September 2008, Teaching and Learning Foreign Languages in the National Educational System, Period 2008-2020. (English Translation). Accessed on 26 March 2020. Available from http://vanban.chinhphu.vn/portal/page/por- 
tal/chinhphu/hethongvan-

ban?class_id=1\&_page $=2 \&$ mode $=$ detail $\&$ document_id=78437

Igawa, K., 2008. Professional development needs of EFL teachers practicing in Japan and Korea. International Buddhist University Bulletin, 45: 431-455.

Johnson, K. E., Golombek, P. R. (Eds.), 2011. Research on second language teacher education: A sociocultural perspective on professional development. New York, NY: Routledge.

Le Xuan Mai, Nguyen Thi Minh Trang, 2019. Professional Development for Highschool Teachers: A Case in the Mekong Delta. Proceedings of $1^{\text {st }}$ International Conference on Innovation of Teacher Education: Twenty Years of Development: A Model for Inner-Institutional Teacher Training. National University Press. Ha Noi, 74-85.

Mahmoudi, F., Özkan, Y., 2015. Exploring experienced and novice teachers' perceptions about professional development activities. Procedia-Social and Behavioral Sciences, 199: 57-64.

Ministry of Education and Training, 2013. Competency Framework for English Language Teachers: User's Guide. Hanoi: Vietnam Education Publishing House.
Noom-Ura, S., 2013. English-teaching problems in Thailand and Thai teachers' professional development needs. English Language Teaching, 6(11): 139-147.

Özdemir, S. M., 2013. Exploring the Turkish teachers' professional development experiences and their needs for professional development. Online Submission, Mevlana International Journal of Education, 3(4): 250-264.

Richards, J. C., \& Farrell, T. S. C., 2005. Professional development for language teachers: Strategies for teacher learning. New York: Cambridge University.

Richards, J. C., \& Farrell, T. S. C., 2011. Practice teaching: A reflective approach. Cambridge University Press.

Roux, R., Valladares, J. L. M., 2014. Professional development of Mexican secondary EFL teachers: Views and willingness to engage in classroom research. English Language Teaching, 7(9): 21-27.

Shawer, S., 2010. Classroom-level teacher professional development and satisfaction: teachers learn in the context of classroom-level curriculum development. Professional development in education, 36(4): 597-620.

Zein, M. S., 2016. Professional development needs of primary EFL teachers: perspectives of teachers and teacher educators. Professional Development in Education, 43(2): 293-313. 